\title{
Prevention of injury by early socialization of aggressive behavior
}

\section{R E Tremblay}

Injury Prevention 2002;8(Suppl IV):iv17-iv21

See end of article for author's affiliation .....................

Correspondence to: Dr R E Tremblay, GRIP University of Montreal,' 3050 Edouard-Montpetit, Suite A-210, Montreal, Quebec, Canada, H3T 1J7; grip@umontreal.ca
Frequent use of physical aggression by humans appears to reach its peak between 2 and 3 years of age. In the following years most children learn alternatives to physical aggression. Approximately $4 \%$ of children have high levels of physical aggression from early childhood to late adolescence. These children can be considered to show chronic physical aggression. They are at high risk of causing injuries to others and to themselves. They are also at high risk of many other co-morbid mental health conditions, school failure, substance abuse, depression, unemployment, spouse abuse, child abuse, and suicide. There is some evidence that, because of their risky style of behavior, they are also at high risk of many other medical conditions such as cardiovascular problems, cancer, and brain damage. Socialization of aggressive behavior during the preschool years should help prevent injuries throughout the life span.
$\mathrm{T}$ he scientific literature on the development of human physical aggression has been severely handicapped by the aggregation of disruptive, delinquent, and antisocial behaviors, all under the heading of "aggressive behavior". This clearly creates an important problem when the aim is to understand the origin and development of any one of these behavior problems. Protection from physical aggression is probably the main reason why there is so much public interest in deviant-antisocial-delinquent behavior. However, most assessments of deviant-antisocial-delinquent behavior confound physical aggression with many other forms of problem behavior. This situation can be observed by examining the content of the "aggression" scales, which have been used over the past decades. Most of the popular scales contain a mix of behaviors that range from physical aggression to attention seeking and disobedience. For example, one of the most frequently used "aggression" rating scales for children and adolescents $^{1}$ includes the following items: "argues, brags, demands attention, disobeys, poor peer relations, jealous, lies, shows off, stubborn, moody, sulks, loud". The common denominator of these items is that they annoy others. Of the 23 items that make up the Achenbach and Edelbrock "aggression" scale, only two clearly refer to physical aggression while two others can be interpreted as describing physical aggression. This review focuses on research that measured physical aggression.

\section{DEVELOPMENT OF PHYSICAL AGGRESSION DURING THE SCHOOL YEARS}

Most studies of youth physical violence have concentrated on 12-18 year old adolescents. During this period children become physically stronger, their cognitive competence increases (for example, they are better at hiding their intentions), they become sexually mature, they ask and obtain more freedom with regard to spending time without adult supervision, and they have access to more resources such as money and transportation, which increases their capacity to satisfy their needs.

Although a majority of adolescents will commit some delinquent acts, most of these are minor legal infractions. Population based surveys have systematically shown that a small proportion of adolescents (approximately 6\%) account for the majority of violent acts and arrests. ${ }^{2}$ The challenge is to explain why some adolescents and some adults frequently resort to physically aggressive behavior while others do not. Although they are relatively small in number, they frighten a large part of the population, and they represent a heavy burden of suffering for their victims, their families, and themselves. Adolescents with behavioral problems are also much more likely to be unemployed, suffer poor physical health, and have mental health problems. ${ }^{3-6}$

A number of high profile cases have made it poignantly clear that extremely violent behavior does not suddenly appear with adolescence. For example, in March 2000, a Michigan kindergarten boy used a semi-automatic handgun to kill a female classmate in the classroom. ${ }^{7}$ These rare cases serve as a reminder that young children can be extremely violent. In fact, longitudinal studies of large samples of boys and girls followed from school entry to the end of adolescence clearly show that younger children are more frequently physically aggressive; as they grow older they generally resort to less and less physical aggression. ${ }^{89}$

Interestingly, these patterns are completely reversed in the case of indirect aggression, which is defined as behavior aimed at hurting someone without the use of physical aggression. For example, a child who is mad at someone may say bad things behind the other's back or may try to get others to dislike that person. Females tend to have higher levels of indirect aggression compared to males at each age, and the level of indirect aggression increases with age for girls and boys. ${ }^{11}$ Thus, the process of socialization may involve learning to use indirect means of aggression rather than physical aggression.

Although recent longitudinal studies of physical aggression have made it clear that the majority of school age children are less and less physically aggressive with time, ${ }^{12}$ many continue to believe that a minority of children commence or increase the frequency of their acts of physical aggression as they grow older. This issue was recently addressed by the mapping of different developmental trajectories. Results from the Montreal Longitudinal-Experimental study of boys, assessed regularly from 6 to 15 years of age (fig 1), showed that $17 \%$ of the boys appeared never to have been physically aggressive; $4 \%$ exhibited a high frequency of physical aggression from 6 to 15 years of age; $28 \%$ started with a high level of physical aggression at age 6 and became less and less physically aggressive with time; while the majority (52\%) had a low level of physical aggression at age 6 and also became less and less 


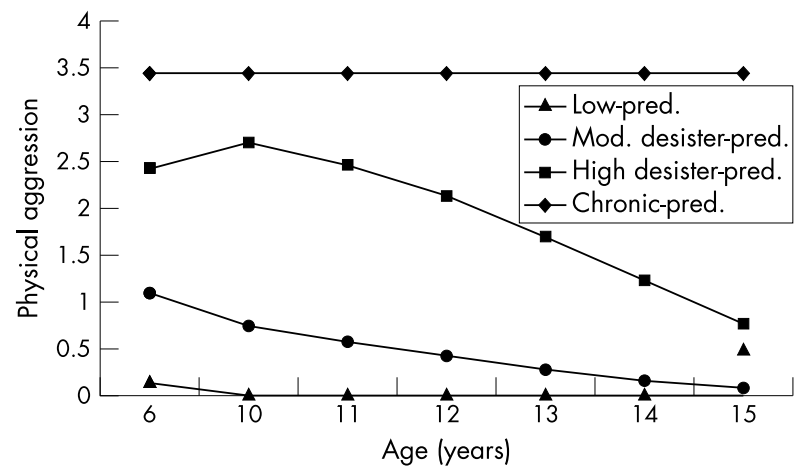

Figure 1 Developmental trajectories of physical aggression for boys from 6 to 15 years of age.

aggressive with time. ${ }^{13}$ In contrast to hypotheses concerning late onset of antisocial behavior, this study and others that followed ${ }^{14}$ did not find any group of boys or girls in which there appeared to be an "onset" and maintenance of moderate or high levels of physical aggression for a significant number of years after age 6 . They also observed that for every group of boys the peak level for frequency of physical aggression was during the first year of the study when they were in kindergarten.

These results clearly challenge the idea that the frequency of physically aggressive acts increases with age. They also challenge the notion that there is a significant group of children who show chronic physical aggression during late childhood or adolescence after having successfully inhibited physical aggression throughout childhood. If, between kindergarten and high school, children are at their peak level of physical aggression during their kindergarten year, when do they actually start to aggress physically?

\section{DEVELOPMENT OF PHYSICAL AGGRESSION DURING THE PRESCHOOL YEARS}

There are surprisingly few longitudinal studies that have tried to chart the development of physical aggression during the preschool years. This lack of attention to physical aggression during the early years appears to be the result of a long held belief that physical aggression appears during late childhood and early adolescence as a result of bad peer influences, television violence, and increased levels of male hormones. ${ }^{15-18}$ This view of antisocial development was very clearly described more than 200 years ago by Jean-Jacques Rousseau in his book on the education of Émile (1762/1979). ${ }^{19}$

Longitudinal studies of small samples of preschool children have found that the most physically aggressive toddlers tend to remain the most aggressive preschoolers. ${ }^{20-22}$ However, cross sectional data ${ }^{11}$ on a sample of close to $200002-11$ year old Canadian children gave the first epidemiological indication that the mean frequency of physical aggression peaks between the second and third year after birth and then steadily declines (fig 2).

So, if the frequency of physical aggression is at its highest at the end of the second year after birth, at what age does physical aggression begin? Within a longitudinal study of a large sample of babies born in the province of Quebec in the mid-1990s, mothers were asked to rate the frequency of physical aggression at ages 17 and 30 months and, at both times, to indicate at what age the child had started to show such behavior. ${ }^{23}$ At age 17 months, close to $90 \%$ of the mothers reported that their child was physically aggressive toward others at least sometimes. Figure 3 shows the cumulative age of onset of pushing others to get what you want. Very few children are reported to use that behavior before 12 months of age. However, by 24 months more than half of the children have been reported to use that behavior. Note that a difference between males and females starts to appear around 15 months of age. One of the interesting results of that study is the fact that mothers who were reporting at 17 months that their child had started to hit others in the previous months appeared to have forgotten this early onset, since they were reporting at age 30 months that their child had started to hit others after 17 months of age. This memory failure as children grow older, taller, and bigger could in part explain why parents of physically aggressive adolescents report that the aggression problems started only a year or two before. ${ }^{9}$

\section{WHY DOES PHYSICAL AGGRESSION PEAK AT THE END OF INFANCY?}

From an evolutionary perspective, would it make sense that the species that managed to dominate planet earth needed to learn to physically aggress? Research on the development of aggression over the past half century was largely dominated by the social learning hypothesis. ${ }^{24}$ The question being asked was "how do children learn to physically aggress?". The recently observed normative decline in physical aggression

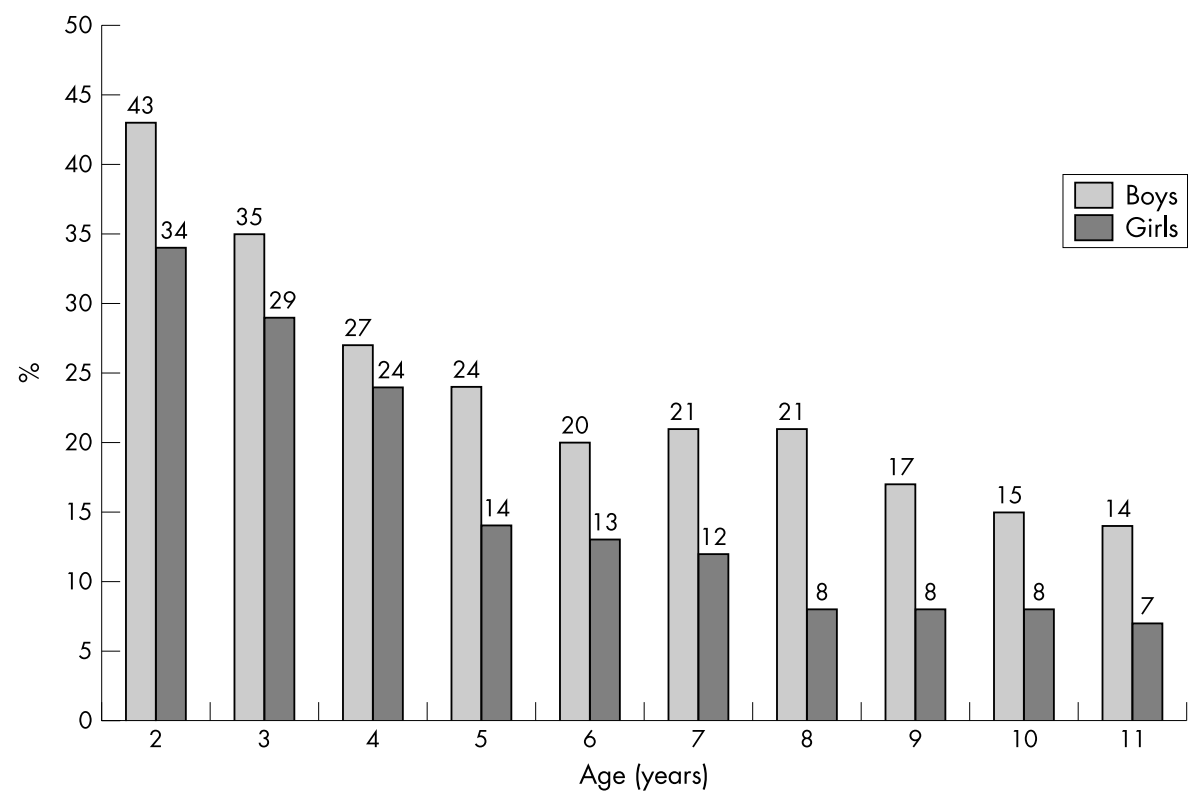

Figure 2 Percent children using physical aggression (NLSCY, 1994). 


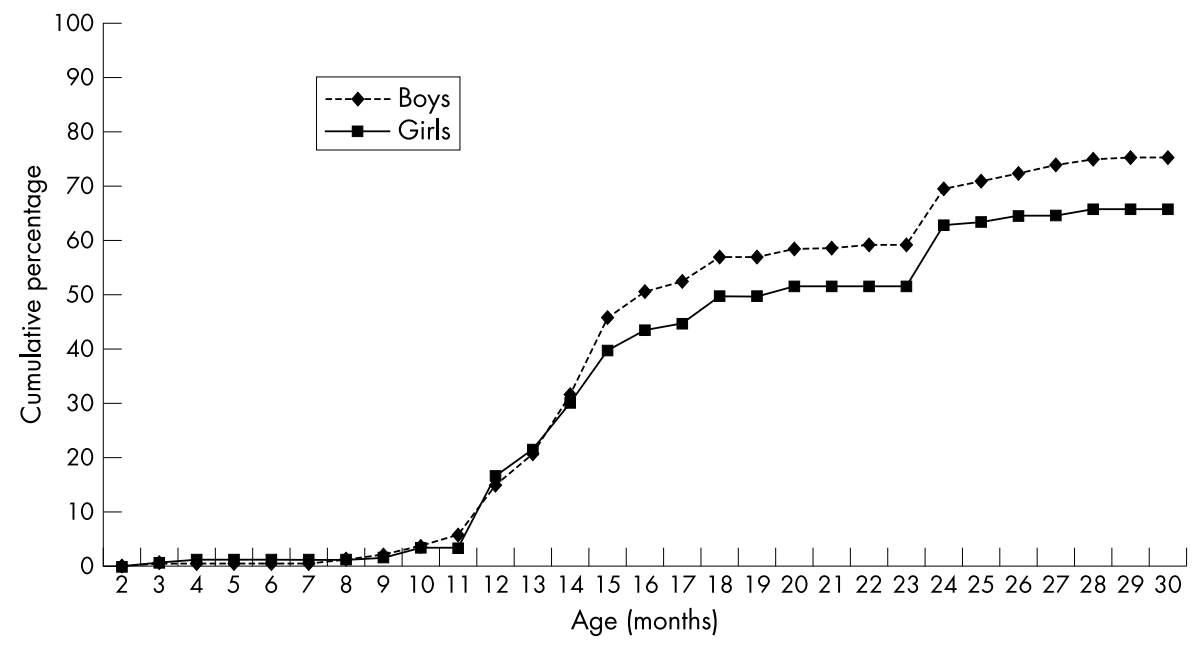

Figure 3 Pushes others to get what he/she wants.

from 2 to 3 years of age onwards implies that the right question to ask is "how do children learn not to physically aggress?".

One would expect that physical, cognitive, and emotional development play an important role in learning not to physically aggress. Within the first 24 months after birth, babies grow in height by more than $70 \%$, and almost triple their weight. At birth babies can hardly lift their heads, nine months later they can move on all fours, by 12 months they can walk, and by 24 months they can run and climb stairs. The ability to grasp objects is an important development for social interactions. At birth babies do not control their arms, at 6 months they can reach and grasp for objects. If they see an interesting toy in the hands of another 9 month old, they will reach and grasp the toy. A struggle for the toy will occur if the other child does not let go. Note that, at 9 months, the child does not have the language ability to ask the other child for the toy-this ability will develop over the next two years-but the frequency and complexity of interactions between babies and other persons in their environments increase at least as rapidly as their physical growth. Infants' waking time is spent exploring their physical environments. Before 12 months of age, they spend most of their playtime exploring one object at a time. Between 12 and 18 months, they imitate real life activities alone. By the end of the second year they are "pretend playing" with others. ${ }^{25}$

Thus, over the first 15 months after birth, with increased physical mobility and cognitive competence, children also become more and more able to discover their environment. The frequency of their interactions with peers increases with age, and playing with others increases dramatically from the end of the first year to the end of the second year. ${ }^{26}$ This is the period when the rate of physical aggression increases to its maximum. At this age, children are exploring social interactions with their newly acquired walking, talking, running, grasping, pushing, kicking, hitting, and throwing skills. Most of their interactions are positive, but conflicts become more frequent. ${ }^{27}$ Most of these conflicts are over possession of objects and territories. During these conflicts children learn that they can hurt and be hurt. Most children will quickly learn that a physical attack on a peer will be responded to by a physical attack, and that adults will not tolerate these behaviors. Most children will learn to wait for the toy to be free, and that asking for toys rather than taking them away from someone will more likely prevent negative interactions.

Learning to wait for something you want (delay of gratification $)^{28}$ and learning to use language to convince others to satisfy your needs may be the most important protective factors against chronic physical aggression. Numerous studies have shown an inverse correlation of verbal skills with impul- sivity and criminal behavior. ${ }^{29}{ }^{30}$ We need to understand the mechanisms underlying these associations. They are clearly operating in the first two years of life.

By 12 months of age, children have the physical, cognitive, and emotional means of being physically aggressive toward others. It appears that most children will at some point hit, bite, or kick another child or even an adult. ${ }^{23}$ Children's individual characteristics can explain part of the variance in the frequency and stability of this behavior, but the quality of children's relations with their environment, and the environment's reaction to this behavior, will very likely be important factors. If children are surrounded by adults and other children who are physically aggressive, they will probably learn that physical aggression is part of everyday social interactions. On the other hand, if a child lives in an environment that does not tolerate physical aggression, and rewards prosocial behavior, it is likely that the child will acquire the habit of using means other than physical aggression to obtain what he or she wants, or for expressing frustration.

\section{PREVENTION OF CHRONIC PHYSICAL AGGRESSION}

The normal course for the development of physical aggression during the life span of humans appears to be a rapid increase during infancy and a continuous decrease up to adulthood. ${ }^{89}{ }^{23}$ However, some infants use physical aggression more often than others, and a subset of these maintain high levels of physical aggression up to late adolescence. ${ }^{13} 142131-33$ Research has identified a number of predictors for chronic physical aggression, which could be used to plan prevention experiments. The predictors can be divided into three categories: (a) individual characteristics such as obstetric complications, testosterone, serotonin, body mass, sex, race, ethnicity, temperament, hyperactivity, anxiety, opposition, impulsivity, and cognitive development; (b) physical environmental characteristics such as cigarette smoke and lead content; and (c) social environmental characteristics such as social cohesion of neighborhood, parent characteristics, family characteristics, and school characteristics.

\section{The role of individual characteristics}

From a developmental perspective, genetic inheritance is the original individual characteristic. The number of genetic studies of behavior problems has increased substantially in the past decade. There are very few genetic studies of childhood physical aggression, ${ }^{34}$ and no genetic studies of chronic physical aggression trajectories to our knowledge. However, twin and adoption studies have shown substantial genetic influence, and gene-environment interactions on risk regarding different assessments of broadly defined antisocial behavior. ${ }^{35-39}$ A number of molecular genetic studies have 
linked genes to the risk of impulsive and aggressive behavior through neurotransmitter metabolizing enzymes (MAOA) and serotonin receptors. ${ }^{40-43}$ In cases where impulsive and aggressive behavior would be due to genetically determined levels of MAOA and serotonin, one would expect these behaviors to be present in early childhood when extra environmental support could be given to help the child learn to regulate his aggressive behavior.

Many other individual characteristics have been linked to physical aggression and antisocial behavior: hormones, cardiovascular activity, brain physiology, brain functioning, temperament, physical development, cognitive functioning, emotional responses, social development, and moral development. ${ }^{447}$ In most studies only a small number of individual characteristics were studied, and most did not take into account genetic information and physical environmental characteristics. A small subset of social environmental characteristics was usually taken into account.

\section{The role of physical environments}

The list of physical environment characteristics that could potentially lead to chronic physical aggression, as well as to occasional physical aggression is very long. Most chemicals, which have an effect on the developing nervous system, could have an impact on the control over physical aggression. There is accumulating evidence that cigarette and alcohol use during pregnancy increases the risk of cognitive and behavior problems. ${ }^{45}$ 48-55 Among chemicals that could have an impact after birth, studies of lead exposure during childhood show links to externalizing behavior problems. ${ }^{56}$

Other important physical environmental determinants of physical aggression are the availability of weapons. Most studies have focused on availability of guns during adolescence, but many children have access to firearms and knives, and are often trained to use them. Children with chronic physical aggression are likely to be more attracted by weapons, more likely to live in environments where they are easily available, and less likely to be trained to use them safely. Housing studies have also shown that the physical organization of living, schooling, and leisure environments can increase or decrease the likelihood of deviant behavior, including physical aggression. ${ }^{57-59}$

\section{The role of the social environment}

Most developmental studies of aggression have concentrated on psychosocial determinants. Associations have been shown with characteristics of parents, families, parenting behavior, siblings, peers, teachers, schools, and neighborhoods. ${ }^{60}{ }^{61}$ Two important limits to these studies are that physical aggression was not specifically targeted, and other determinants, especially physical environments and genetics, were not considered. Some studies have shown important interactions between social and biological determinants. ${ }^{40} 4562$

A major problem with research on the development of physical aggression is that most studies had relatively small samples, most did not start during pregnancy, most did not measure physical aggression during the preschool years, and each assessed only part of the risk factors. We clearly need large scale longitudinal studies, which will measure the developmental course of physical aggression from infancy to late adolescence, and measure all the putative risk factors from pregnancy onwards to study the interplay among the factors. Within these longitudinal studies, we should also experiment the most likely effective interventions to prevent the development of chronic physical aggression.

\section{CONCLUSIONS}

No longitudinal studies have yet mapped the development of physical aggression from early childhood to adulthood. However, separate longitudinal studies of large samples of children during early childhood, and during the school years, have helped understand that children start to learn to regulate physical aggression during early childhood. These studies indicate that the best time to start preventing the development of chronic physical aggression is early childhood. However, since humans need to learn not to physically aggress, situational prevention is necessary throughout the life span to prevent the primitive instincts from piercing through the thin veneer of civility we acquire.

Large prospective longitudinal studies with repeated measurement of appropriate individual and environmental characteristics, from pregnancy onwards, will provide an opportunity to study the developmental sequences of risk factors associated with physical aggression. However, to understand developmental mechanisms we need experimental research. From a pragmatic perspective, the most cost effective and ethical way of doing research on child development is to nest prevention trials within longitudinal studies ${ }^{63-65}$ Preventive interventions during pregnancy and early childhood are likely to have beneficial effects on numerous outcomes, including physical health, mental health, school performance, criminal behavior, labor activity, and family socioeconomic status. ${ }^{66-70}$ Such experiments would help test cumulative effect hypotheses, ${ }^{71} 72$ and hypotheses of multiple outcomes of early biological embedding of environmental effects. ${ }^{73}$

\section{ACKNOWLEDGEMENTS}

The research leading to this paper was made possible by grants from the Social Sciences and Humanities Research Council of Canada, the Québec fund for research training and support to research (FCAR), the Québec health research fund (FRSQ), the Québec council for social research (CQRS), the Molson Foundation, the Canadian Institute for Advanced Research, and the Canadian Institutes of Health Research.

\section{Author's affiliation}

R E Tremblay, University of Montreal, Canada

\section{REFERENCES}

1 Achenbach TM, Edelbrock C. Manual for the child behavior checklist and revised child behavior profile. Burlington, VT: University of Vermont, Department of Psychiatry, 1983.

2 Farrington DP. Epidemiology. In: Quay HC, ed. Handbook of juvenile delinquency. New York: John Wiley \& Sons, 1987:33-61

3 Bardone AM, Moffitt T, Caspi A, et al. Adult mental health and social outcomes of adolescent girls with depression. Dev Psychopathol 1996;8:811-29.

4 Farrington $\mathbf{D}$. Key results from the first forty years of the Cambridge study in delinquent development. In: Thornberry T, Krohn MD, eds. Longitudinal research in the social and behavioral sciences. New York: Kluwer/Plenum. In press.

5 Kokko K, Pulkkinen L. Breaking the cycle of maladaptation. Prevention \& Treatment 2000;3.

6 Hagen J. The social embeddedness of crime and unemployment. Criminology 1993;31:465-91.

7 Rosenblatt R. The killing of Kayla. Time Magazine 2000;March:16-19.

8 Cairns RB, Cairns BD, Neckerman HJ, et al. Growth and aggression: 1. Childhood to early adolescence. Dev Psychol 1989:25:320-30.

9 Loeber R, Stouthamer-Loeber M. Development of juvenile aggression and violence. Some common misconceptions and controversies. Am Psychol 1998;53:242-59

10 Biörkqvist K, Österman K, Kaukiainen A. The development of direct and indirect aggressive strategies in males and females. In: Biörkqvist $\mathrm{K}$, Niemelä $\mathrm{P}$, eds. Of mice and woman: aspects of female aggression. Toronto: Academic Press, 1992:51-64.

11 Tremblay RE, Boulerice B, Harden PW, et al. Do children in Canada become more aggressive as they approach adolescence? In: Human Resources Development Canada, Statistics Canada, eds. Growing up in Canada: National Longitudinal Survey of Children and Youth. Ottawa: Statistics Canada, 1996:127-37

12 Tremblay RE. The development of aggressive behaviour during childhood: what have we learned in the past century? Int J Behav Dev 2000;24:129-41.

13 Nagin D, Tremblay RE. Trajectories of boys' physical aggression, opposition, and hyperactivity on the path to physically violent and non violent juvenile delinquency. Child Dev 1999;70:1181-96.

14 Broidy LM, Nagin DS, Tremblay RE, et al. Developmental trajectories of childhood disruptive behaviors and adolescent delinquency: a six site, cross national study. Dev Psychol. In press. 
15 Elliott DS, Huizinga D, Ageton SS. Explaining delinquency and drug use. Beverly Hills, CA: Sage, 1985.

16 Ellis L, Coontz PD. Androgens, brain functionning, and criminality: the neurohormonal foundations of antisociality. In: Ellis L, Hoffman $\mathrm{H}$, eds. Crime in biological, social and moral contexts. New York: Praeger, 1990: 162-93.

17 Huesmann LR, Miller LS. Long-term effects of repeated exposure to media violence in childhood. In: Huesmann LR, ed. Aggressive behavior current perspectives. New York: Plenum Press, 1994:153-86.

18 Johnson JG, Cohen P, Smailes EM, et al. Television viewing and aggressive behavior during adolescence and adulthood. Science 2002;295:2468-71

19 Rousseau JJ. Émile, de l'éducation. Paris: Firmin Didot Frères et Fils, 1762

20 Cummings EM, lannotti R, Zahn-Waxler C. Aggression between peers in early childhood: individual continuity and developmental change. Child Dev 1989;60:887-95.

21 Hay DF, Castle J, Davies L. Toddlers' use of force against familiar peers: a precursor of serious aggression? Child Dev 2000;71:457-67.

22 Keenan K, Shaw DS. The development of aggression in toddlers: a study of low-income families. J Abnorm Child Psychol 1994;22:53-77.

23 Tremblay RE, Japel C, Pérusse D, et al. The search for the age of "onset" of physical aggression: Rousseau and Bandura revisited. Criminal Behavior and Mental Health 1999:9:8-23.

24 Bandura A. Aggression: a social learning analysis. New York: Holt, 1973

25 Rubin KH, Fein GG, Vandenberg B. Play. In: Mussen PH, ed. Handbook of child psychology. New York: Wiley, 1983:693-774.

26 Ross HS, Goldman BD. Infants' sociability toward strangers. Child Dev 1977;48:638-42.

27 Restoin A, Montagner H, Rodriguez D, et al. Chronologie des comportements de communication et profils de comportement chez le jeune enfant. In: Tremblay RE, Provost MA, Strayer FF, eds. Ethologie et développement de l'enfant. Paris: Editions Stock/Laurence Pernoud, 1985:93-130.

28 Mischel W, Shoda Y, Rodriguez ML. Delay of gratification in children. Science 1989;244:933-8.

29 Moffitt TE. Adolescence-limited and life-course persistent antisocial behavior: a developmental taxonomy. Psychol Rev 1993;100:674-701.

30 Stattin $\mathbf{H}$, Klackenberg-Larsson I. Early language and intelligence development and their relationship to future criminal behavior. J Abnorm Psychol 1993; 102:369-78

31 Brame B, Nagin DS, Tremblay RE. Developmental trajectories of physical aggression from school entry to late adolescence. J Child Psychol Psychiatry 2001;58:389-94.

32 Keenan K, Wakschlag LS. More than the terrible twos: the nature and severity of behavior problems in clinic-referred preschool children. J Abnorm Child Psychol 2000;28:33-46.

33 White HR, Bates ME, Buyske S. Adolescence-limited versus persistent delinquency: extending Moffitt's hypothesis into adulthood. J Abnorm Psychol 2001;1 10:600-9

34 Dionne G, Tremblay RE, Boivin M, et al. Physical aggression and expressive vocabulary in 19 month-old twins. Dev Psychol. In press.

35 Bock GR, Goode JA, eds. Genetics of criminal and antisocial behavior. CIBA Foundation Symposium 1994. Toronto: John Wiley \& Sons, 1996.

36 Lyons JJ, True WR, Eisen SA, et al. Differential heritability of adult and juvenile antisocial traits. Arch Gen Psychiatry 1995;52:906-15.

37 Plomin R, Nitz K, Rowe DC. Behavioral genetics and aggressive behavior in childhood. In: Lewis M, Miller SM, eds. Handbook of developmental psychopathology. New York: Plenum Press, 1990:119-33

38 Silberg J, Rutter M, Meyer J, et al. Genetic and environmental influences on the covariation between hyperactivity and conduct disturbance in juvenile twins. J Child Psychol Psychiatry 1996;37:803-16.

39 Slutske WS, Heath AC, Dunne MP, et al. Modeling genetic and environmental influences in the etiology of conduct disorder: a study of 2,682 adult twin pairs. J Abnorm Psychol 1997; 106:266-79

40 Caspi A, McClay J, Moffitt T, et al. Role of genotype in the cycle of violence in maltreated children. Science 2002;297:851-4.

41 Coccaro EF, Kavoussi RJ, Cooper TB, et al. Central serotonin activity and aggression: inverse relationship with prolactin response to d-fenfluramine, but not CSF 5-HIAA concentration, in human subjects. Am J Psychiatry 1997; 154:1430-5

42 Goldman D, Lappalainen J, Ozaki N. Direct analysis of candidate genes in impulsive behaviors. In: Bock GR, Goode JA, eds. Genetics of criminal and antisocial behavior. CIBA Foundation Symposium 1994. Toronto: John Wiley \& Sons, 1996: 139-52

43 Higley JD, Mehlman PT, Poland RE, et al. CSF testosterone and 5-HIAA correlate with different types of aggressive behaviors. Biol Psychiatry 1996;40: 1067-82

44 McCord J, Widom CS, Crowell NE. Juvenile crime, juvenile justice. Washington: National Academy Press, 2001

45 Raine A. Annotation: The role of prefrontal deficits, low autonomic arousal, and early health factors in the development of antisocial and aggressive behavior in children. J Child Psychol Psychiatry 2002;43:417-34.
46 Reiss AJ, Roth JA. Understanding and preventing violence, Vol. 4: Consequences and control. Washington, DC: National Academy Press, 1994.

47 Tremblay RE, LeMarquand D. Individual risk and protective factors. In: Loeber R, Farrington D, eds. Child delinquents: development, interventions and service needs. Thousand Oaks, CA: Sage Publications, 2001:137-64.

48 Brennan PA, Grekin ER, Mednick SA. Maternal smoking and criminal outcomes. Arch Gen Psychiatry 1999;56:215-19.

49 Ernst M, Moolchan ET, Robinson ML. Behavioral and neural consequences of parental exposure to nicotine. J Am Acad Child Adolesc Psychiatry 2001;40:630-41.

50 Eskenazi B, Castorina R. Association of prenatal maternal or postnatal child environmental tobacco smoke exposure and neurodevelopmental and behavioral problems in children. Environ Health Perspect 1999; 107:991-1000.

51 Fergusson DM. Prenatal smoking and antisocial behavior. Arch Gen Psychiatry 1999;56:223-4.

52 Orlebecke JF, Knol DL, Verhulst FC. Child behavior problems increased by maternal smoking during pregnancy. Arch Environ Health 1999;54:15-19.

53 Rasanen $\mathbf{P}$, Hakko $\mathrm{H}$, Isohanni $M$, et al. Maternal smoking during pregnancy and risk of criminal behavior among adult male offspring in the Northern Finland 1966 birth cohort. Am J Psychiatry 1999; 156:857-62.

54 Wakschlag LS, Lahey BB, Loeber R, et al. Maternal smoking during pregnancy and the risk of conduct disorder in boys. Arch Gen Psychiatry 1997;54:670-6.

55 Weissman MM, Warner V, Wickramaratne PJ, et al. Maternal smoking during pregnancy and psychopathology in offspring followed to adulthood. J Am Acad Child Adolesc Psychiatry 1999;38:892-9.

56 Wasserman GA, Staghezza-Jaramillo B, Shrout $P$, et al. The effect of lead exposure on behavior problems in preschool children. Am J Public Health 1998;88:481-6.

57 Clarke RV. Situational crime prevention. In: Tonry M, Farrington DP eds. Building a safer society: strategic approaches to crime prevention. Chicago: The University of Chicago Press, 1995:91-150.

58 Katz LF, King JR, Liebman JB. Moving to opportunity in Boston: early results of a randomized mobility experiment. Working Paper no. 441. Industrial Relations Section, Princeton University, 2000.

59 Lasley JR. Using traffic barriers to design out crime. Report to the National Institute of Justice. California State University, Fullerton, 1996.

60 Loeber R, Farrington DP. Child delinquents: development, interventions and service needs. Thousand Oaks, CA: Sage Publications, 2001.

61 Loeber R, Farrington DP. Serious and violent juvenile offenders: risk factors and successful interventions. Thousand Oaks, CA: Sage Publications, 1998.

62 Arseneault L, Tremblay RE, Boulerice B, et al. Obstetrical complications and violent delinquency: testing two developmental pathways. Child Dev 2002;73:496-508.

63 Lacourse E, Côté S, Nagin DS, et al. A longitudinal-experimental approach to testing theories of antisocial behavior development. Dev Psychopathol. In press.

64 Tonry M, Ohlin LE, Farrington DP, et al. Human development and criminal behavior: new ways of advancing knowledge. New York: Springer-Verlag, 1991

65 Tremblay RE, Kurtz L, Mâsse LC, et al. A bimodal preventive intervention for disruptive kindergarten boys: its impact through mid-adolescence. J Consult Clin Psychol 1995;63:560-8.

66 Olds DL, Henderson CR, Chamberlin R, et al. Preventing child abuse and neglect: a randomized trial of nurse home visitation. Pediatrics 1986;78:65-78.

67 Olds D, Henderson CR, Cole R, et al. Long-term effects of nurse home visitation on children's criminal and antisocial behavior: fifteen-year follow-up of a randomized controlled trial. JAMA 1998:280:1238-44.

68 Shonkoff JP, Phillips DA, eds. From neurons to neighborhoods: the science of early child development. Washington, DC: National Academy Press, 2000.

69 Tremblay RE, LeMarquand D, Vitaro F. The prevention of ODD and CD. In: Quay HC, Hogan AE, eds. Handbook of disruptive behavior disorders. New York: Kluwer Academic/Plenum Publishers, 1999:525-55

70 Weikart DP, Schweinhart L. High/Scope preschool program outcomes. In: McCord J, Tremblay RE, eds. Preventing antisocial behavior: interventions from birth to adolescence. New York: Guilford Press, 1992:67-86.

71 Coie JD, Watt NF, West SG, et al. The science of prevention: a conceptual framework and some directions for a National Research Program. Am Psychol 1993;48:1013-22.

72 Yoshikawa H. Prevention as cumulative protection: effects of early family support and education on chronic delinquency and its risks. Psychol Bull $1994 ; 115: 28-54$

73 Keating DP, Hertzman C. Developmental health and the wealth of nations. New York: Guilford Press, 1999.

74 Meaney MJ, Aitken DH, Van Berkel C, et al. Effect of neonatal handling on age-related impairments associated with the hippocampus. Science 1988;239(4841, pt 1):766-8. 